\title{
Recognition and Capability - Prerequisites for Empowerment for Children with Disabilities?
}

\author{
Christina Strandholdt Andersen ${ }^{1}$ (D)
}

Accepted: 2 February 2022 /Published online: 14 February 2022

(c) The Author(s) 2022

\begin{abstract}
This theoretical study explores the empowerment perspective regarding children with disabilities. Article 12 of the UNCRC states children's right to express their views and be listened to. Meanwhile, studies show that children with disabilities are at risk of overprotection, which may restrict their participation and influence. Honneth's theory of recognition and Sen's Capability Approach are discussed together with the empowerment perspective when it comes to fulfilling article 12 regarding children with disabilities alongside empirical studies. Finally, a new model of dynamic empowerment is suggested to illuminate the interrelational complexity in this matter, as well as a way of identifying and understanding the possible mechanisms that may affect children with disabilities and their participation and influence.
\end{abstract}

Keywords children $\cdot$ disability $\cdot$ empowerment $\cdot$ recognition $\cdot$ capability $\cdot$ rights

\section{Introduction}

In theory, there is a generally accepted relational understanding of disability as a deprivation of participation due to the interaction between the individual and barriers in surroundings (United Nations, 2006). Studies on empowerment and children with disabilities are characterized by a focus on the individual's capacity to participate (Ramcharan, 1997; Ytterhus et al., 2015) and less on power relations or other underlying structures. This view is therefore still greatly influenced by the medical model of disability where the focus is on trying to "repair" the impairment, rather than acknowledging the complex interaction between child and surroundings, as well as recognizing and appreciating the child first. This is the case despite the fact that several studies show that children with disabilities see themselves foremost as children (Andersen et al., 2019; Gustavsson \&

Christina Strandholdt Andersen

christina.strandholdt.andersen@inn.no

1 Faculty of Social and Health Sciences, Inland Norway University of Applied Sciences,

Lillehammer, Norway 
Nyberg, 2015; Smith \& Traustadóttir, 2015). In this way, children with disabilities may therefore be in a different framework than children in general and theory concerning this may need further exploration and alterations. The United Nations Children's Rights Convention (UNCRC), article 12, states that:

States Parties shall assure to the child who is capable of forming his or her own views the right to express those views freely in all matters affecting the child, the views of the child being given due weight in accordance with the age and maturity of the child. (United Nations, 1989)

Meanwhile, article 3 states that adults should protect the best interests of children and young people in general when making choices that affect them. The definitions in these articles in the UNCRC are rather unclear. When is a child capable and mature? Moreover, what is meant by given due weight to their opinion? What is the child's best interest? Therefore, it has been argued that, in many cases, protection of the child prevents the child from achieving influence. This paradox is discussed in different studies concerning children's participation in decisions where protection of the child to a great extent still stands in the way of them having influence (Opdal, 2002; Skivenes \& Strandbu, 2006; Thuen, 2008; van Bijleveld et al., 2015). Thus, children's rights are restricted by adults, as seen in article 12. That is, the adults hold the power to determine when and in which way children may have influence. Together with others (Ulvik, 2009), Thomas and Stoecklin (2018) conclude that

“Children's voices may have legitimacy, but they have little or no effective power” (p. 86).

Thus, children risk being positioned as a vulnerable group, depending on how adults choose to involve them. Hence, the UNCRC article 12 is essentially not fulfilled. When it comes to children with disabilities, this statement is even more current with the risk that the children become overprotected and excluded from having a voice and participating in society (Grue, 2011; Smith \& Traustadóttir, 2015; Tøssebro \& Ytterhus, 2006). An example of this is illustrated in a meta study by Franklin and Sloper (2009), showing that these children are less often asked about their opinions than other children. Furthermore, they are more often bullied or excluded, have less social relations and feel more sad than other children (Bengtsson et al., 2011; Koller et al., 2018). This may lead to low selfesteem and a lesser degree of well-being (Foley et al., 2012; Ytterhus, 2012). Children with disabilities may therefore be viewed as more vulnerable than children in general regarding empowerment.

There is very little research regarding children with disabilities and their right to express their views and to be listened to as stated in the UNCRC, article 12 (Ytterhus et al., 2015). The purpose of this study is, therefore, to discuss new possible ways of approaching the empowerment perspective regarding children with disabilities, in order to move a step closer to fulfilling the UNCRC article 12.

Besides describing two main approaches in empowerment literature, I will present and discuss Thomas and Stoecklin's contribution to children's participation 
and influence in general (Thomas \& Stoecklin, 2018), based on article 12. They believe that Honneth's theory of recognition and Sen's Capability Approach present a new framework in which to understand how children can achieve their rights. Examples from studies of children with disabilities and their views on participation and influence will be brought into the discussion to illuminate and explore the theoretical approach. In addition, a new model of empowerment by Shier (2019) and implications for practice by Clark et al. (2019), based on the capability approach together with participation and empowerment literature, will be included here. Finally, a new model of dynamic empowerment is presented as a contribution to the exploration and understanding of the empowerment perspective regarding children with disabilities.

\section{Empowerment}

Two main approaches in the area of empowerment are individual empowerment and community empowerment. Historically, empowerment has its roots in the "Black Power" movement and the feminist movement, including processes of collective consciousness raising and resistance (Askheim, 2010; Freire, 2000; Spencer, 2014). Individual empowerment focuses on building the individual's capacity to gain greater control, whereas community empowerment addresses collective action towards social change of suppressive structures and social inequalities (Askheim, 2012; Spencer, 2014). The social model of disability is an example of this perspective where disability is regarded as a result of attitudes and structures in society rather than a medical condition (Oliver, 2013). In recent times, health and social care have been criticized for taking an individualistic approach that does not include the broader relationships of power that define the limits of people's opportunities to "choose". The term empowerment does not have one clear definition and has been used in many ways. This, however, does not make its eligibility less valid. When it comes to empowerment and disability, Cocks and Cockram (1997) speak of three levels:

Empowerment at a personal level means freedom from the avoidable constraints that come from one's impairment and from the limiting attitudes of other people. At the systemic level, it means freedom from the misguided actions of formal human services and other social institutions; and at the societal level, societal values and ideologies that promote vulnerability and disempowerment (p. 224).

The citation refers to an inherent capacity to participate and to have influence on one's own life. At the same time, the surroundings must support the person in the process through awareness, facilitating the conditions and not least, through recognition.

In this article, the empowerment perspective is related to the UNCRC, which states basic human rights specifically aimed at children. In particular, article 12 expresses the right for the child to participate and have influence on his or her own 
life. So, how can we apply this to children with disabilities? In the following, Honneth's theory of recognition and the Capability Approach by Sen are first presented as a way of understanding how children in general can achieve their rights.

\section{Recognition and Capability}

Thomas and Stoecklin (2018) connect children's rights with two concepts; Honneth's theory of recognition (Honneth, 2006) and Sen and Nussbaum's Capability Approach (Nussbaum, 2000; Sen, 1999). The first concept has its primary focus on identity and the latter on activity. Thomas and Stoecklin suggest combining the two to enable children to exercise in real life the rights that they already have by law. Here, the following questions are relevant:

"Where and how do children achieve reciprocal recognition (how are children cared for, how are their rights respected, in what ways are they valued)? What resources and what conversion factors enable them to achieve what functionings?" (p. 91).

The two theories will now each be presented and then summarized together with the empowerment perspective.

\subsection{Recognition}

According to Honneth, human identity is constructed through mutual recognition processes. He describes three forms of recognition that have a bearing on personal identity and thus self-realization, also called a positive self-relationship. These are love, rights and solidarity. Love from one's primary relationships, legal relations in the form of being regarded as a full member of the society of equal rights, and, finally, social appreciation, where the individuality and diversity of persons are valued. If all three forms of recognition are present, the person has the opportunity to live a free life with participation and influence. Love is the most elementary form of recognition. Here, the child's basic self-confidence is grounded, which forms the foundation of a positive self-relationship on the path to an independent life. Rights and solidarity constitute the other conditions for a positive self-relationship in the form of self-respect and self-esteem (Honneth, 2006).

Honneth has not directly linked his theory to children, except when it comes to recognition as love. However, as already mentioned, Thomas and Stoecklin (2018) also apply Honneth's other forms of recognition to children, focusing on children as valid community members based on children's research as well as the UNCRC:

In other words, the model invites us to look at children not only as recipients of care and affection but also as givers of care and affection, and as rights-bearers and rights-respecters, and as potential, if not actual, members of a community of solidarity based on shared values and reciprocal esteem (p. 78).

The right to be regarded as a valid member of society must therefore also apply to children with disabilities. Thomas and Stoecklin emphasize that reflexive thinking 
about the child's own identity is of great importance to the child's motivations, based on Honneth's theory of recognition. To refer these concepts of recognition to children with disabilities in particular, thus, the child's experience of his or her body, including the impairment, as well as the perceptions by the surroundings, may have an impact on the child's self-perception and thereby also on the motivation for influence on his or her own life. With the third form of recognition, children with or without an impairment should be recognized and appreciated who he or she is regardless of his or her diversity. Being considered valuable for the person you are in the community that you are in, can boost self-esteem in the child, which in turn contributes to a positive self-relationship.

Honneth's theory of recognition has been criticized, among others by Taylor and Fraser, for underestimating the distribution of power and resources, and that his theory is primarily based on Western European terms and philosophy (Thomas \& Stoecklin, 2018). Thomas and Stoecklin therefore argue, that a combination of Honneth's theory and the Capability Approach may contribute to fulfil the gaps that each theory has.

\subsection{The Capability Approach}

The Capability Approach originates from a theory within welfare economics (Sen, 1999) and has since been broadened out, in relation to children's rights (Golay \& Malatesta, 2014; Thomas \& Stoecklin, 2018) and disability (Mitra, 2006; Trani et al., 2011) as well as empowerment (Clark et al., 2019), however separately. The following presentation is based on a combination of these references and considers children with disabilities and empowerment in terms of achieving their right to express their views and to be listened to according to the UNCRC, article 12.

Overall, capability means practical opportunity and refers to a person's real freedom in terms of achieving functioning. Functioning includes activities and desirable states. In other words, the Capability Approach focuses on whether people are capable to do and be how they wish to act and be. Capabilities are based on resources available (commodities) and personal, social and environmental factors that enable the person to convert the resources into functioning. Freedom is defined as the choice, ability and opportunity people have to pursue their aspirations. Thus, the Capability Approach is concerned with real freedom and opportunities for people to lead a life that they value (Mitra, 2006; Thomas \& Stoecklin, 2018).

Stoecklin and Bonvin (2014) have presented a model applying the Capability Approach to children's rights (Fig. 1). They argue that there will always be a gap between children's formal rights and their real freedom to participate, i.e. capability. Factors necessary to convert rights into reality include personal factors (such as the child's impairment) and social factors (such as attitudes in society). The model illustrates children's decision-making process as a complex interrelation between children's reflexivity, that of adults, and the opportunities offered by actual structures. One must therefore consider which factors convert article 12 (individual entitlement) into real influence and participation for the child. At the same time, the child's achieved functioning affects the social definition of article 12 as well as personal 


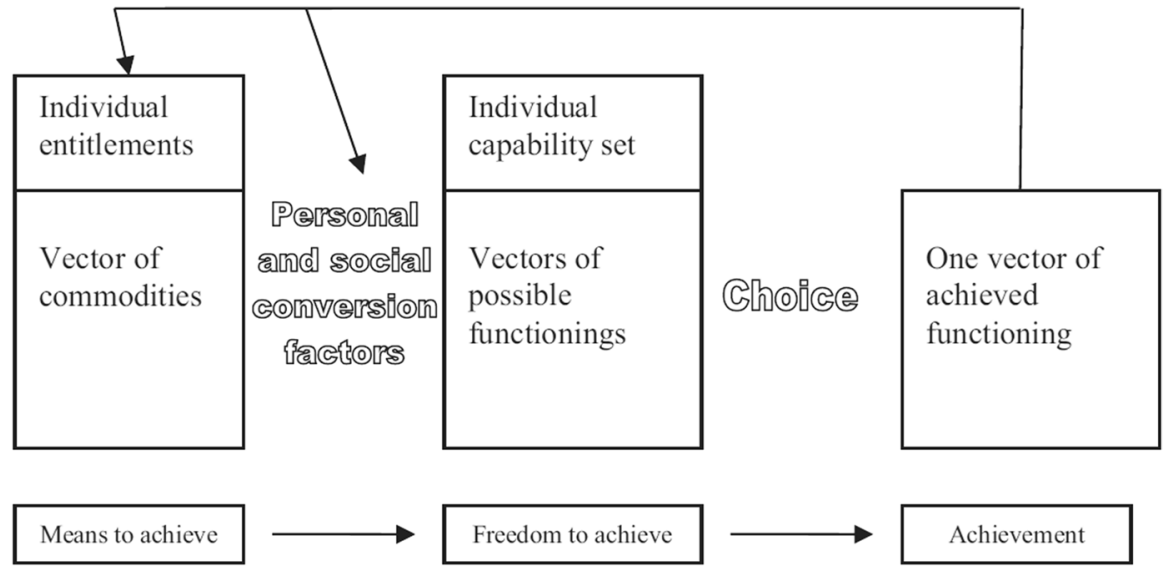

Fig. 1 From entitlements and commodities to achieved functionings (Stoecklin \& Bonvin, 2014, p. 134)

and social factors and, thereby, the child's ever-evolving capability set. This means that children themselves can influence how article 12 can be understood, and that the children's actual choices to a great extent are dependent on their own understanding of their rights.

Mitra (2006) and Trani et al. (2011) also refer to the Capability Approach as a way of understanding disability as a deprivation of capabilities or functionings, due to the interaction between the resources available to the person, personal characteristics and the environment. By using the Capability Approach, children with disabilities and their well-being is, therefore, not only linked to either their impairment (i.e. the medical model) or the disabling conditions (i.e. the social model) (Trani et al., 2011). Mitra here argues that the Capability Approach is a useful framework for defining disability. As written by Sen (1999):

"A person who is disabled may have a larger basket of primary goods and have less chance to lead a normal life (or to pursue her objectives) than an able-bodied person with a smaller basket of primary goods" (p. 74).

Mitra (2006) suggests a model combining the Capability Approach with existing disability models (Fig. 2).

Disability occurs when a person is deprived of practical opportunities because of his or her impairment. For example, when a child is restricted in participating at school or in leisure activities in contrast to a child with similar commodities, in a similar environment and with similar personal characteristics except for the impairment. Mitra refers to this as potential disability. Actual disability is when the person cannot do or be the things he or she values doing or being at the functional level. A consequence may be that the person adapts to the deprivation over time and, in this way, feels less disabled. Using the Capability Approach, disability may result from different factors: The impairment itself (personal characteristics), for example if a child has epilepsy and because of that is not allowed to dive underwater; the resources available to the person, for example a functional wheelchair for a child with cerebral palsy for transportation (commodities); and/ 


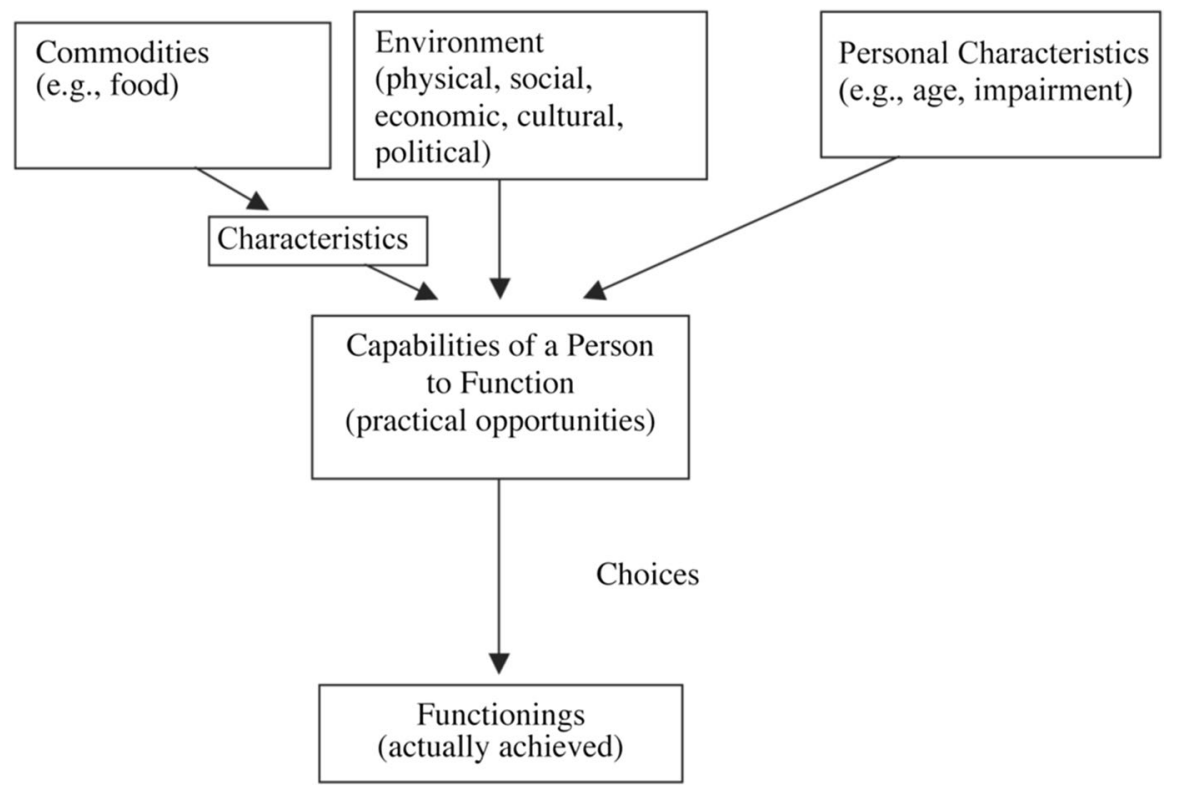

Fig. 2 The Capability Approach (Mitra, 2006, p. 240)

or the environment, for example if the child is bullied or excluded because of his or her impairment.

An overall common critique of the Capability Approach is that it can be difficult to operationalize for policy planning because of its complexity and openness. This also challenges research regarding empowerment for children with disabilities and children overall to think in new methodologies and frameworks when it comes to children's participation, influence and well-being.

\subsection{Empowerment, Recognition and the Capability Approach - a summary}

For children to be able to achieve their rights, Thomas and Stoecklin (2018) conclude that children must be recognized as members of their community with real freedom to pursue a life that they value. Children must not only be seen as becomings but also as beings. The recognition and capability perspective could help in developing new ways to influence this empowerment process for children with disabilities. The Capability Approach may also help in overcoming the dichotomy between the medical and social model and thus be a framework for a relational understanding of disability.

There is very little research concerning children with disabilities and the UNCRC, article 12, and not least when it comes to their views and experiences concerning this right (Cavet \& Sloper, 2004). I will therefore now discuss the UNCRC, article 12 and the presented theory together with relevant studies on children with disabilities and their views on their rights, in order to illuminate how the empowerment perspective might be relevant and in what way. 


\section{Discussion}

To start with, the question is; is empowerment relevant for children with disabilities? In short, the answer is - yes. Article 12 in the UNCRC is a basic right for children, which is not fulfilled in many cases, and in particular, not when it comes to children with disabilities. How is it relevant then? In this article, children with disabilities and empowerment have been identified with first of all, the relational understanding of disability together with children's rights and theories of recognition and capability. These concepts intertwine with each other when trying to understand the complexity of empowerment for these children. In the following, the presented theory will be related to studies concerning children with disabilities and their reflections on and experiences with the UNCRC article 12, a theme which Thomas and Stoecklin (2018) find is missing in research in general. Clark et al. (2019) and Shier (2019) have contributed to the empowerment perspective regarding children and youth, which will be part of the discussion. Finally, a summarizing conclusion will be presented followed by a suggested new model of dynamic empowerment.

\subsection{Protection Versus Influence}

As mentioned in the introduction, a paradox lies in the UNCRC, article 12, where adults decide when and how to involve children in decisions. At the same time, article 3 expresses that protection of the child comes before other rights.

Using the model of Stoecklin and Bonvin (2014) concerning capacity and children's rights, which possible commodities as well as personal and social factors may be at stake when it comes to children with disabilities and their participation and influence? When looking at research studies concerning children with disabilities and their views and experiences with participation and influence, the children most often express that they don't have a say or only are involved in small decisions (Andersen \& Dolva, 2015; Stafford et al., 2003; Young et al., 2006). However, some studies have identified that the children accept and/or understand why it is so and adapt to it (Andersen et al., 2019; Coyne \& Gallagher, 2011; Stafford et al., 2003). Meanwhile, studies show that children with disabilities state that it is important to be able to express one's opinions (Andersen et al., 2019; Cavet \& Sloper, 2004; Mårtenson \& Fägerskiöld, 2008; Stafford et al., 2003). However, some children with disabilities believe that it is more important to be recognized rather than being the one in charge of decisions (Andersen et al., 2019; Coyne \& Gallagher, 2011; Stafford et al., 2003). The children understand that they need surgery, physiotherapy etc. to be as able as possible. Much focus is therefore on seeing the children as becomings rather than beings because of their impairment, i.e. individual factors, which reduces chances of becoming as normal as possible. The adults surrounding the children, and the children themselves, prioritize treatment in the best interest of the child, even though it takes time from friends and leisure. The balance here is difficult, since the children, at the same time, see themselves foremost as children and not as disabled. Other factors may be that some children have experienced a lack of understanding and of being excluded from their surroundings along with physical 
limitations in their environment creating barriers for participation, speaking one's mind and having influence (Andersen et al., 2019). Retrospective studies and literature support these statements, showing that adolescents with disabilities wish that they had had more opportunities to feel part of a peer community and perhaps not spend as much time on treatment (Grue, 2019; Smith \& Traustadóttir, 2015).

Honneth's recognition theory has been used to interpret the children with disabilities and their perspectives and experiences with participation and influence (Andersen et al., 2019). Findings show that the children were recognized at home, as Honneth's first sphere of love. However, there was a lack of recognition when it came to their rights and solidarity outside the home. According to this article, Honneth's theory of recognition has great importance regarding children with disabilities and article 12. Thus, it is important to recognize the child with disabilities in specific situations where decisions are made, but also in general when it comes to culture and attitudes in society and everyday settings. Interestingly, the children who participated in this study mostly experienced themselves as disabled in interaction with their surroundings outside of their homes. When they were at home, they were recognized for who they were in a familiar environment and were just seen as children. Referring to Mitra (2006), this means that their actual disability was mainly experienced when they were confronted with their impairment due to attitudes or physical limitations.

Based on this discussion, it seems that children with disabilities and their right to participate and have influence are counteracted by over-protection of the child, limitations in their surroundings and not recognizing the child as an equal to other children nor as able to fulfil their rights, because of their impairment and how it is challenged in society. The question here is how and in what way is empowerment possible for children with disabilities with so many constraints and restrictive attitudes in their lives?

\subsection{The UNCRC Article 12 and Children With Disabilities - Empowerment As a Dynamic Model?}

As mentioned before, Thomas and Stoecklin (2018) believe that a new framework based on a combination of Honneth's theory of recognition and Sen's Capability Approach may help children to be recognized and have the freedom to achieve their rights.

Clark et al. (2019) also emphasize the importance of children's participation and influence and regard the Capability Approach as a way of seeing children as active agents. They believe that a cultural change is needed and suggest a change in the educational system as an arena for empowerment processes. Social and educational policies should encourage children's involvement in decision-making, for instance by creating "communities of inquiry" where children can reflect upon and decide what they want to be and become. Inspired by Freire (2000) and the Capability Approach, Clark et al. (2019) present four components for empowerment referred to as "Empowered Learning Systems", which are: supportive institutions, relationships of solidarity and trust, critical pedagogy and emancipatory outcomes. They suggest 
processes that facilitate "bottom-up" actions and ownership in local communities as well as facilitating "bottom-down" learning and introducing new opportunities for mutual cooperation and development. Emancipatory research could be well suited for this empowerment process. They conclude that a further development combining the capability and participatory approaches could empower people's participation in research and decision-making processes that shape their lives.

Shier (2019) has in fact presented a model of empowerment developed by young people illustrating how they experience the process of empowerment (Fig. 3). It shows the interaction between capability, conditions/opportunities and attitude, where the children must have knowledge and ability, be supported by their surroundings and, finally, recognize themselves, in order to have influence.

Here, empowerment is understood as a process linking three essential factors: capability, conditions and opportunities, and, thirdly, attitude. Hence, the child or youth must be supported by his or her surroundings in order to have influence, the child or youth must have the knowledge and ability required to have influence and, foremost, the child or youth must recognize him or herself in order to have influence. Shier's model is the first model of child and youth empowerment that is developed by youth themselves and must therefore be seen as an important contribution.

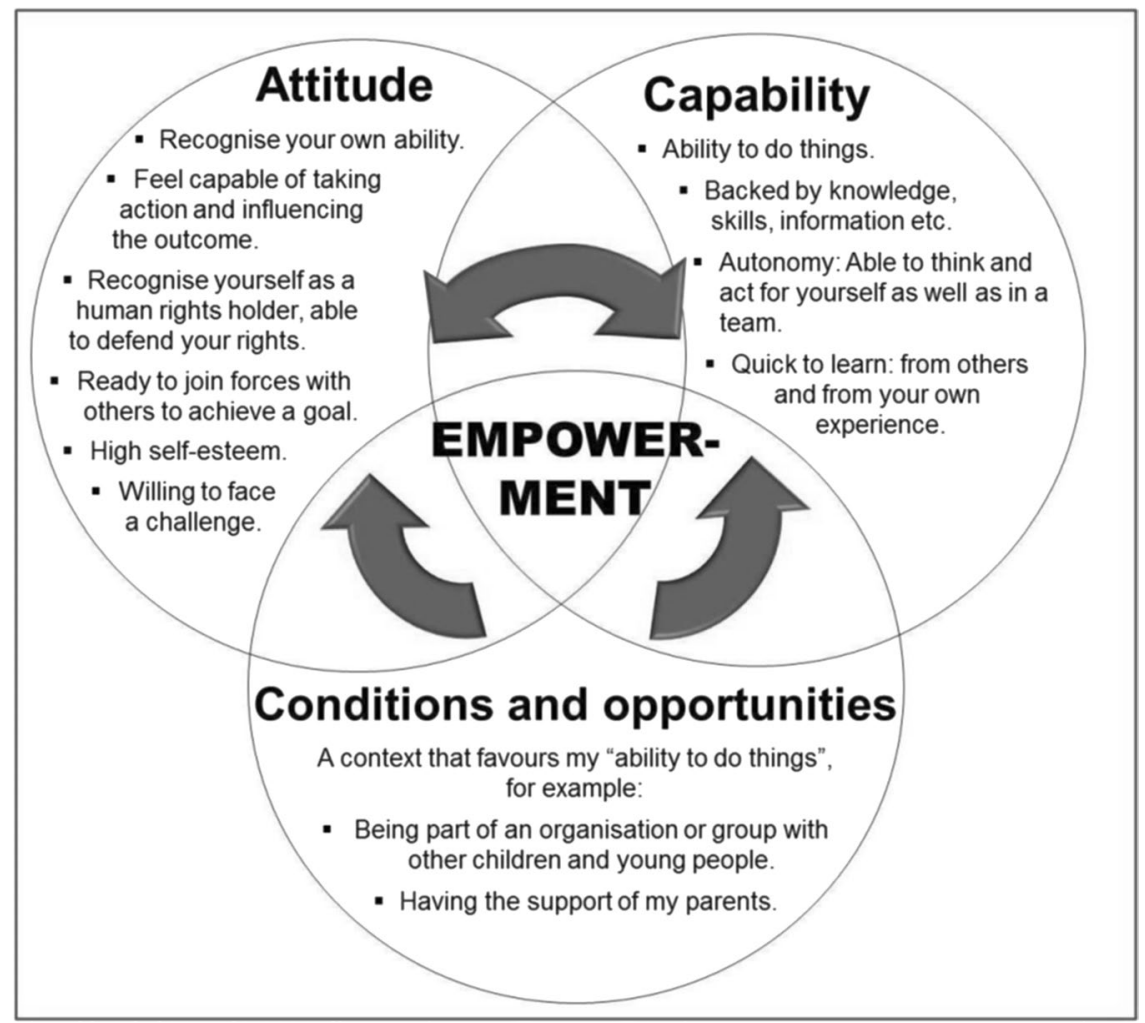

Fig. 3 The CESESMA model of Empowerment (Shier, 2019, p. 3) 
In this relation, Shier asks if this model could be a starting point for a universal concept of empowerment for children and youth. To counter this question, I believe it is important to discuss what the model shows and does not show and to whom. Young people's experiences present an important insight to adults in how they can be supported in the process of empowerment. However, the model mostly pays attention to the child or youth themselves in its present form than to the surroundings, where the surroundings seem more implicit in the model. Examples of this can be seen in the child's ability to do things (capability), which are dependent on information from others. The dynamics in the model also show a one-directional interrelation between conditions and opportunities and the other components, whereas a bidirectional interrelation is illustrated when it comes to attitude and capabilitiy. On this matter, the details of conditions and opportunities could be elaborated to show the complex interrelation between child and surroundings. Structural and cultural restraints may for example inhibit the child or youth in the development of critical awareness (Freire, 2000) and thereby their opportunity to uncover these very same mechanisms to be able to act upon them. Otherwise, the risk may be that the model could be used as individual empowerment where other external factors, such as social injustice, power, attitudes etc. might not be taken into account and dealt with.

So, how may the concepts of recognition and capability presented in this article, regarding children in general, contribute to children with disabilities and their participation and influence? In the following, an attempt of incorporating the complex interrelations between possible factors is presented in a model of dynamic empowerment, inspired by the literature presented (Fig. 4):

The model illustrates a dynamic systemic understanding of how each component may influence the others in the overall process of empowerment. A change in one place affects the whole of the child with disabilities and his or her surroundings. For example, if a child experiences pain and fatigue from cerebral palsy (personal characteristics) which causes limited energy to participate and have influence, and thereby affects functionings, this lack of energy may be counteracted, if the child has a positive experience, for instance with peers (environment) or feels recognized by the medical surgeon when considering surgery (recognition). At the same time, the child's involvement may for instance, have influence on the child's attitude and recognition of him or herself (recognition) as well as the adults' view of the child as capable. The model invites to choose where focus lies, i.e., identifying a challenge or need and then exploring the possible factors that may inhibit participation and influence, and thereby functionings. In this regard, the model is intended to have a more holistic perspective that goes beyond the dichotomy between the individual and the community empowerment perspective as well as the social model versus the medical model. Finally, it helps illuminating the complex life world that children with disabilities often are in, from the individual relational level to overall legislations, cultures and attitudes in society, that in some ways may contain even more challenges than with children in general. The presented theory and examples from empirical studies confirm that children, and especially children with disabilities, are in need of a framework to help promoting their chance to participate and have influence. 


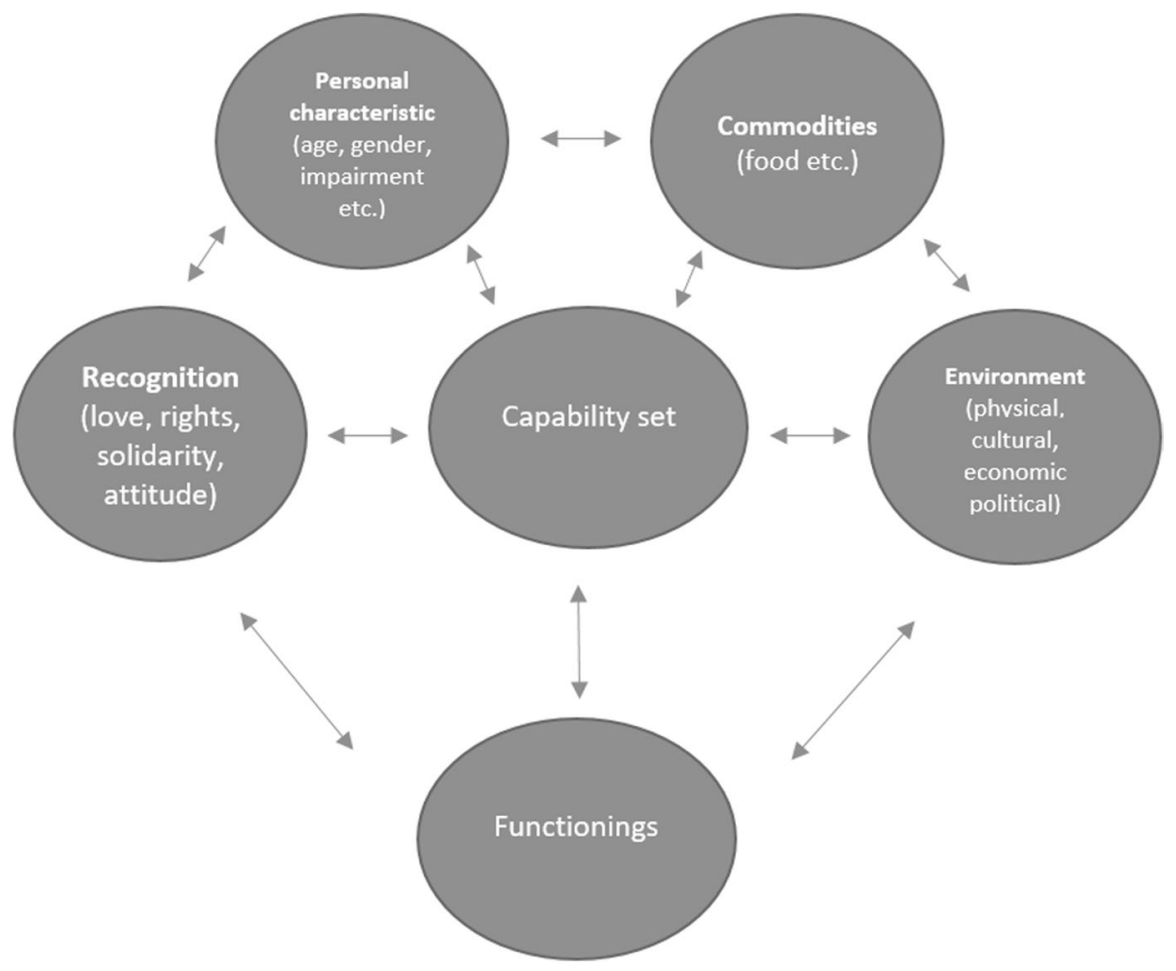

Fig. 4 Model of Dynamic Empowerment (Developed by the author)

\section{Conclusion}

The UNCRC article 12 is in some ways a recognition of child empowerment, but in many ways, it is still not fulfilled, and particularly not when it comes to children with disabilities. Within the statement itself lies a paradox, where it is up to adults to judge whether the child needs protection more than influence. When it comes to empowerment for children, and, in particular, children with disabilities, in terms of achieving their rights, Honneth's recognition theory and Sen's Capability Approach are seen in much of the literature found. The combination of the two concepts seems to grasp the complexity and vulnerable positions of children not only as becomings but also as beings. This could be a way forward in influencing cultural attitudes towards recognizing children with disabilities as not only vulnerable, but as rights-bearers that are capable and, in many cases, want to speak their minds and have influence if they are supported. Many good intentions are found in theories about children's participation and influence, as already seen in Thomas and Stoecklin, Shier and Clark et al. The author of this article has also made an attempt to contribute to the field with a systemic model of empowerment as a dynamic perspective. The question is how to implement these theories of empowerment processes 
in children's everyday lives? Clark et al. has suggested emancipatory research and a focus on agency in education as a way forward for children in general. However, when it comes to children with disabilities, the author of this article believes Honneth's theory of recognition is crucial. In the process of cultural change, there must be an emphasis on appreciating diversity, i.e. recognizing each child for who they are and taking this into account, for example when it comes to didactic considerations in school. Anti-bullying campaigns and NEST (Network and Educational Skills Training) teaching (Koenig et al., 2009) may be examples of such initiatives. Welfare technology and universal designs are other examples of making the physical surroundings more accessible to all and thereby reducing stigmatization, for example building slopes instead of stairs and having automatic doors when it comes to wheelchair users ensuring accessibility to public buildings such as schools etc.

In addition to the process of cultural change, it is also important recognizing the constraints faced by children with disabilities in particular, such as treatments and restrictions due to the impairment, as well as attitudes in society and within themselves concerning their disability. Positive role models in the public arena could be an example of trying to change cultural attitudes, such as politicians, supermodels or artists with disabilities, music, or children's literature about disability etc. Role models whose story is not about how they were empowered despite their impairment, but perhaps even because of it. It is not enough to teach children with disabilities to reflect upon their own needs and wishes without also bringing their reality into the discussion. Because often the children already have taken this into account and adapted to it in their actions and attitudes in everyday life. The model of dynamic empowerment is an attempt to explore these underlying mechanisms regarding children with disabilities and their participation and involvement, combining the theories presented in this article with studies concerning children with disabilities and empowerment. The model could be used as a framework for empowerment processes with children with disabilities and should also be further developed together with the children. Hopefully, it will contribute to a more holistic exploration in research, as well as practice and attitudes regarding children with disabilities.

Funding Open Access funding provided by Inland Norway University Of Applied Sciences.

\section{Declarations}

Conflicts of Interest The author has no relevant financial or non-financial interests to disclose. The author has no conflicts of interest to declare that are relevant to the content of this article.

Open Access This article is licensed under a Creative Commons Attribution 4.0 International License, which permits use, sharing, adaptation, distribution and reproduction in any medium or format, as long as you give appropriate credit to the original author(s) and the source, provide a link to the Creative Commons licence, and indicate if changes were made. The images or other third party material in this article are included in the article's Creative Commons licence, unless indicated otherwise in a credit line to the material. If material is not included in the article's Creative Commons licence and your intended use is not permitted by statutory regulation or exceeds the permitted use, you will need to obtain permission directly from the copyright holder. To view a copy of this licence, visit http://creativecommons.org/licen ses/by/4.0/. 


\section{References}

Andersen, C. S., Dolva, A.-S. \& Askheim, O. P. (2019). "Det er godt sådan i det hele taget at kunne sige, hvad man vil og ikke vil" - Børn med funktionshæmning og deres refleksioner omkring deltagelse og indflydelse på eget liv ["It is good to be able to say what you want and what you don't want" - Children with disabilities and their reflections on participation and influence in their everyday lives]. Barn, 37(34), 119-130. doi: https://doi.org/10.5324/barn.v37i3-4.3384

Andersen, C. S., \& Dolva, A.-S. (2015). Children's perspective on their right to participate in decision-making according to the United Nations Convention on the Rights of the Child. Physical \& Occupational Therapy In Pediatrics, 35(3), 218-230. https://doi.org/10.3109/01942638.2014.918075

Askheim, O. P. (2010). Empowerment - Ulike tilnærminger [Empowerment - Different approaches]. In O. P. Askheim \& B. Starrin (Eds.), Empowerment: I teori og praksis. (pp. 21-34). Gyldendal akademisk.

Askheim, O. P. (2012). Empowerment $i$ helse- og sosialfaglig arbeid: Floskel, styringsverktфy, eller frigjøringsstrategi? [Empowerment in health and social work: A phrase, management tool or liberating strategy?]. Gyldendal akademisk.

Bengtsson, S., Hansen, H., \& Røgeskov, M. (2011). Børn med funktionsnedsattelse og deres familier - Den første kortlagning $i$ Norden [Children with disabilities and their families - The first Nordic overview]. SFI - Det Nationale Forskningscenter for Velfærd. https://www.vive.dk/da/udgivelser/boern-med-enfunktionsnedsaettelse-og-deres-familier-4452/

Cavet, J., \& Sloper, P. (2004). Participation of disabled children in individual decisions about their lives and in public decisions about service development. Children \& Society, 18(4), 278-290. https://doi.org/10. 1002/chi.803

Clark, D. A., Biggeri, M., \& Frediani, A. A. (2019). Participation, empowerment and capabilities: Key lessons and future challenges. In D. A. Clark, M. Biggeri, \& A. A. Frediani (Eds.), The capability approach, empowerment and participation: Concepts, methods and applications (pp. 385-403). Palgrave Macmillan. doi: https://doi.org/10.1057/978-1-137-35230-9

Cocks, E., \& Cockram, J. (1997). Empowerment and the limitations of formal human services and legislation. In P. Ramcharan, G. Roberts, G. Grant, \& J. Borland (Eds.), Empowerment in everyday life: Learning disability (pp. 222-240). Jessica Kingsley Publishers.

Coyne, I., \& Gallagher, P. (2011). Participation in communication and decision-making: Children and young people's experiences in a hospital setting. Journal of Clinical Nursing, 20(15/16), 2334-2343. https:// doi.org/10.1111/j.1365-2702.2010.03582.x

Foley, K.-R., Blackmore, A. M., Girdler, S., O’Donnell, M., Glauert, R., Llewellyn, G., \& Leonard, H. (2012). To feel belonged: The voices of children and youth with disabilities on the meaning of wellbeing. Child Indicators Research, 5, 375-391. https://doi.org/10.1007/s12187-011-9134-2

Franklin, A., \& Sloper, P. (2009). Supporting the participation of disabled children and young people in decision-making. Children \& Society, 23(1), 3-15. https://doi.org/10.1111/j.1099-0860.2007.00131.x

Freire, P. (2000). Pedagogy of the oppressed. Continuum.

Golay, D., \& Malatesta, D. (2014). Children's councils implementation: A path toward recognition? In D. Stoecklin \& J.-M. Bonvin (Eds.), Children's rights and the capability approach: Challenges and prospects (pp. 109-130). Springer. doi: https://doi.org/10.1007/978-94-017-9091-8_6

Grue, J. (2019). Jeg lever et liv som ligner deres: En levnetsbeskrivelse [I live a life similar to theirs: A biography] (2nd ed.). Gyldendal.

Grue, L. (2011). Barn og unge med nedsatt funksjonsevne [Children and youth with disabilities]. In E. V. Lunde, B. Lerdal, \& L. H. Stubrud (Eds.), Habilitering av barn og unge: Tiltak for helsefremming og mestring. (pp. 21-35). Universitetsforlaget.

Gustavsson, A., \& Nyberg, C. (2015). "I am different, but I'm like everyone else": The dynamics of disability identity. In R. Traustadóttir, B. Ytterhus, S. T. Egilson, \& B. Berg (Eds.), Childhood and disability in the Nordic countries: Being, becoming, belonging (pp. 69-85). Palgrave Macmillan. doi: https://doi.org/ $10.1057 / 9781137032645$

Honneth, A. (2006). Kamp om anerkendelse: Sociale konflikters moralske grammatik [The struggle for recognition - The moral grammar of social conflicts]. Hans Reitzels forlag.

Koenig, K. P., Bleiweiss, J., Brennan, S., Cohen, S., \& Siegel, D. E. (2009). The ASD Nest Program: A model for inclusive public education for students with autism spectrum disorders. TEACHING Exceptional Children, 42(1), 6-13. https://doi.org/10.1177/004005990904200101 
Koller, D., Pouesard, M. L., \& Rummens, J. A. (2018). Defining social inclusion for children with disabilities: A critical literature review. Children \& Society, 32(1), 1-13. https://doi.org/10.1111/chso.12223

Mitra, S. (2006). The capability approach and disability. Journal of Disability Policy Studies, 16(4), $236-247$. https://doi.org/10.1177/10442073060160040501

Mårtenson, E. K., \& Fägerskiöld, A. M. (2008). A review of children's decision-making competence in health care. Journal of Clinical Nursing, 17(23), 3131-3141. https://doi.org/10.1111/j.1365-2702.2006. 01920.x

Nussbaum, M. C. (2000). Women and human development: The capabilities approach. Cambridge University Press.

Oliver, M. (2013). The social model of disability: Thirty years on. Disability \& Society, 28(7), 1024-1026. https://doi.org/10.1080/09687599.2013.818773

Opdal, P. M. (2002). Barnerettighetene [Children's rights]. Mennesker og rettigheter., 20(4), 2-10.

Ramcharan, P. (1997). Empowerment in everyday life: Learning disability. Jessica Kingsley.

Sen, A. (1999). Development as freedom. Oxford University Press.

Shier, H. (2019). "Empowerment" of children and adolescents: What is it, how does it occur, and what is the adult supporter's role? Finding answers in the experience of young people organising with CESESMA in Nicaragua. 1-13. https://www.childrensresearchnetwork.org/files/CRN_Article-4_Final_-HarryShier.pdf

Skivenes, M., \& Strandbu, A. (2006). A child perspective and children's participation. Children, Youth and Environments, 16(2), 10-27.

Smith, E., \& Traustadóttir, R. (2015). Childhood disability, identity and the body. In R. Traustadóttir, B. Ytterhus, S. T. Egilson, \& B. Berg (Eds.), Childhood and disability in the Nordic countries: Being, becoming, belonging (pp. 85-101). Palgrave Macmillan. doi: https://doi.org/10.1057/9781137032645

Spencer, G. (2014). Empowerment, health promotion and young people: A critical approach. Routledge.

Stafford, A., Laybourn, A., Hill, M., \& Walker, M. (2003). 'Having a say': children and young people talk about consultation. Children \& Society, 17(5), 361. https://doi.org/10.1002/chi.758

Stoecklin, D., \& Bonvin, J.-M. (2014). Children's rights and the capability approach : Challenges and prospects. Springer.

Thomas, N., \& Stoecklin, D. (2018). Recognition and capability: A new way to understand how children can achieve their rights? In C. Baraldi \& T. Cockburn (Eds.), Theorising childhood: citizenship, rights and participation (pp. 73-95). Palgrave Macmillan.

Thuen, H. (2008). Om barnet: Oppdragelse, opplaring og omsorg gjennom historien [The child: Upbringing, education and care throughout history]. Abstrakt forlaget.

Trani, J.-F., Bakhshi, P., \& Biggeri, M. (2011). Rethinking children's disabilities through the capability lens: A framework for analysis and policy implications. In M. Biggeri, J. Ballet, \& F. Comim (Eds.), Children and the capability approach (pp. 245-270). Palgrave Macmillan.

Tøssebro, J., \& Ytterhus, B. (2006). Funksjonshemmete barn i skole og familie: Inkluderingsideal og hverdagspraksis [Children with disabilitites in school and family: Ideal for inclusion and everday practice]. Gyldendal akademisk.

Ulvik, O. S. (2009). Barns rett til deltakelse - Teoretiske og praktiske utfordringer i profesjonelle hjelperes samarbeid med barn [Children's right to participate - Theoretical and practical challenges in the cooperation with children by professionals]. Tidsskrift for norsk psykologforening, 46(2), 1148-1154.

United Nations. (2006). Convention on the rights of persons with disabilities. https://www.un.org/devel opment/desa/disabilities/convention-on-the-rights-of-persons-with-disabilities.html

United Nations. (1989). Convention on the Rights of the Child. https://www.ohchr.org/EN/ProfessionalInt erest/Pages/CRC.aspx

van Bijleveld, G. G., Dedding, C. W. M., Bunders-Aelen, J. G. F., Science, C., \& Athena, I. (2015). Children's and young people's participation within child welfare and child protection services: A state-ofthe-art review. Child \& Family Social Work, 20(2), 129-138. https://doi.org/10.1111/cfs.12082

Young, B., Moffett, J. K., Jackson, D., \& McNulty, A. (2006). Decision-making in community-based paediatric physiotherapy: A qualitative study of children, parents and practitioners. Health \& Social Care in the Community, 14(2), 116-124. https://doi.org/10.1111/j.1365-2524.2006.00599.x

Ytterhus, B. (2012). Everyday segregation amongst disabled children and their peers: A qualitative longitudinal study in Norway. Children \& Society, 26, 203-213. https://doi.org/10.1111/j.1099-0860.2012. 00433.x 
Ytterhus, B., Egilson, S. T., Traustadóttir, R., \& Berg, B. (2015). Perspectives on childhood and disability. In R. Traustadóttir, B. Ytterhus, S. T. Egilson, \& B. Berg (Eds.), Childhood and disability in the Nordic countries: Being, becoming, belonging (pp. 15-35). Palgrave Macmillan. doi: https://doi.org/10.1057/ 9781137032645

Publisher's Note Springer Nature remains neutral with regard to jurisdictional claims in published maps and institutional affiliations. 